\title{
A LEGAL AESTHETIC OF MEDIEVAL AND PRE-MODERN ARAB-MUSLIM URBAN ARCHITECTURAL SPACE
}

\author{
Simon O'Meara
}

\author{
AMERICAN UNIVERSITY OF KUWAIT
}

Despite growing scholarly awareness of an historical element of Islamic law concerning the regulation of the medieval and pre-modern ArabMuslim medina's architectural environment, a clear statement regarding the history, genealogy, nature, and reach of this element has yet to be made. The present article provides such a report and proposes that this element of Islamic law (figh al-bunyān) be considered a discourse that established a legal aesthetic of architectural space and contributed towards the replication of the medina environment.

The historic medinas common to many parts of the Arab world today are the fruition of a long experiment in Arab-Muslim urban design that has its roots in the pre-Islamic past and its decline in modernity. ${ }^{1}$ The duration and number of phases in this experiment is debatable, ${ }^{2}$ but not the

\footnotetext{
${ }^{1}$ See, inter alia, Hugh Kennedy, 'From Polis to Madina: Urban Change in Late Antique and Early Islamic Syria', Past and Present 106 (1985): 3-27; and André Raymond, 'La structure spatiale de la ville', in Sciences sociales et phénomènes urbains dans le monde arabe: Actes du colloque de l'Association de Liaison entre les Centres de Recherches et Documentations sur le Monde Arabe (ALMA), Casablanca, 30 novembre-2 décembre 1994, ed. Mohammed Naciri and André Raymond (Casablanca: Fondation du Roi Abdul-Aziz AlSaoud pour les Études Islamiques et les Sciences Humaines, 1997), reprinted in André Raymond, Arab Cities in the Ottoman Period: Cairo, Syria and the Maghreb (Aldershot: Ashgate, 2002), 35 (75).

${ }^{2}$ See, for example, Jean-Claude Garcin, 'Le moment islamique (VIIeXVIIIe siècles)', in Mégapoles méditerranéennes: Géographie urbaine rétrospective. Actes du colloque organisé par l'École Française de Rome et la Maison Méditerranéenne des Sciences de l'Homme (Rome, 8-11 mai 1996), ed. Claude Nicolet, Robert Ilbert, and Jean-Charles Depaule (Paris/Rome: Maisonneuve et Larose/École Française de Rome, 2000), 99; Sylvie Denoix, 'Unique modèle ou type divers? La structure des villes du monde arabomusulman à l'époque médiévale', in Mégapoles méditerranéennes, 913-23; and Raymond, 'La structure spatiale de la ville', 75-82 (35-42).
} 
fact that the existing medinas belong to the final phase, ${ }^{3}$ one that was to furnish the empirical data for the otherwise ahistorical concept of 'the Islamic city'. ${ }^{4}$ For the historian André Raymond, this culminating phase dates to approximately $1500-1800$ and is best referred to as 'la ville traditionelle', as opposed to 'la ville classique', the stage that preceded it. ${ }^{5}$ Following a second historian's chronological model, this earlier stage dates to the beginning of the eleventh century. ${ }^{6}$

Although it is no longer possible to experience the spatial structure of this earlier stage, so subsumed was it by what followed, it seems hardly reasonable to conjecture, pace Raymond, that it might have been much different from what replaced it; at least, not with regard to its residential neighbourhoods (sg. hawma, hāra, mahalla, etc.), a large proportion of its fabric. ${ }^{7}$ Not only are building traditions, by definition, resistant to change; more substantively, there exists a body of Islamic law (fiqh) which indicates that a particular type of neighbourhood space was deliberately replicated in the Arab-Muslim medina from approximately the tenth to the nineteenth centuries - a time frame that encompasses both the 'ville classique' and the 'ville traditionelle'. This body of law forms the subject matter of the present article and illustrates a point made by others, including the philosopher and urban critic Henri Lefebvre, that the replication of space is a politically and ideologically motivated choice. $^{8}$

Despite the hiatus between the pioneering work of Robert Brunschvig and that of Besim Hakim, there is now growing awareness of an historical element of Sunni Islamic law that concerns the regulation of the Arab-Muslim medina's architectural environment, most especially its neighbourhoods. Brunschvig's distinction was to offer Western scholarship an appraisal of this regulation, drawing extensively on two key

${ }^{3}$ Jean-Claude Garcin, 'Le moment islamique (VIIe-XVIIIe siècles)', in Mégapoles méditerranéennes, 99; Raymond, 'La structure spatiale de la ville', 75 (35).

${ }^{4}$ Ibid., 35 (75); also Janet Abu-Lughod, 'The Islamic City - Historic Myth, Islamic Essence and Contemporary Relevance', International Journal of Middle East Studies 19 (1987), 155-60.

${ }^{5}$ Raymond, 'La structure spatiale de la ville', 35 (75), but see the important caveat on p. $42(82)$.

${ }^{6}$ Garcin, 'Le moment islamique (VIIe-XVIIIe siècles)', 94.

7 Raymond, 'La structure spatiale de la ville', 35 (75).

${ }^{8}$ Henri Lefebvre, The Production of Space, trans. Donald Nicholson-Smith (Oxford: Blackwell, 1991), passim. 
medieval texts: Kitāb al-qaḍa $\bar{a}^{\supset}$ wa-nafy l-darar ${ }^{c}$ an al-afniya wa-l-țruq wa-l-judur wa-l-mabān̄ wa-l-șāhāat wa-l-shajar wa-l-jamīc (The book of jurisdiction and the elimination of harm regarding houses, streets, walls, buildings, public squares, trees, etc.) by Ibn al-Imām of al-Andalus (d. 991 or 997); and Kitāb al-iclān bi-ahkām al-bunyān (The book of pronouncing judgements in [matters of] building) by Ibn al-Rāmī based in Tunis (d. after 1333). ${ }^{9}$

Forty years later, when Hakim came to the subject, an unpublished Ph.D. thesis referring to the above titles had been written, but little else. ${ }^{10}$ And although his book Arabic-Islamic Cities: Building and Planning Principles tends to oversimplification and has been criticized for being

${ }^{9}$ Robert Brunschvig, 'Urbanisme médiéval et droit musulman', Revue des Études Islamiques 15 (1947): 127-55. For variant titles of these Maliki texts, different editions, and manuscript locations, see Jean-Pierre Van Staëvel's Ph.D.

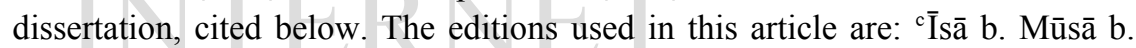
Ahmad b. al-Imām, 'al-Qaḍāo bi-1-mirfaq fī l-mabānī wa-nafy al-ḍarar li-' ${ }^{\circ} \bar{s} \bar{a}$ b. Mūsā b. Aḥmad b. al-Imām al-Tuțîlì’’, ed. Muhammad al-Namīnaj, 2 vols. (Diblūm al-dirāsāt al- ${ }^{c}$ ulyā fì-l-dirāsāt al-islamiyya degree thesis, University of Sidi Mohammed Ben Abdallah, Fez, 1992), hereafter cited as 'Ibn al-Imām' only; Abū 'A Abd Allāh Muḥammad b. Ibrāhīm al-Lakhmī b. al-Rāmī, 'Kitāb ali'lān bi-aḥkām al-bunyān', Majallat al-fiqh al-mālikī wa-l-turāth al-qaḍa $\bar{a}^{\jmath} \bar{l}$ bi-lMaghrib, nos. 2, 3, 4 (1 vol.) (1982): 259-490, hereafter cited as 'Ibn al-Rāmî' only; and idem, al-I'lān bi-ahkām al-bunyān: Abū ${ }^{c}$ Abd Allāh Muhammad b. Ibrāhìm al-Lakhmī b. al-Rāmī al-bannā̄ , ed. Farid Ben Slimane (Tunis: Centre de Publication Universitaire, 1999), hereafter cited as 'Ibn al-Rāmī (2)' only. No translation exists for Ibn al-Rāmī's text, but for Ibn al-Imām's, see Barbier, 'Des droits et obligations entre propriétaires d'héritages voisins', Revue algérienne, tunisienne et marocaine de législation et jurisprudence 16 (1900): 9-15, 17-23, 42-56, 93-104, 113-44; and 17 (1902): 65-84, 89-108.

${ }^{10}$ Saleh A. al-Hathloul, 'Tradition, Continuity and Change in the Physical Environment: The Arab-Muslim City' (Ph.D. dissertation, Massachusetts Institute of Technology, 1981). Additionally, in a special issue of Ekistics (vol. 47/280, Jan/Feb 1980) dedicated to 'Islamic Human Settlements', some articles abridged from The International Symposium on Islamic Architecture and Urbanism (Jan 5-10, 1980, King Faisal University, Damman, Saudi Arabia) had raised the subject. Finally, some court cases involving walls and their maintenance had been mentioned in Galal H. El-Nahal, The Judicial Administration of Ottoman Egypt in the Seventeenth Century (Minneapolis: Bibliotheca Islamica, 1979), 52-53. 
partisan, it was instrumental to the development of the subject as an area of academic research. ${ }^{11}$ In quick succession, other works followed its publication, culminating in the three-volume Ph.D. thesis of Jean-Pierre Van Staëvel, 'Les usages de la ville'. ${ }^{12}$

${ }^{11}$ Besim Selim Hakim, Arabic-Islamic Cities: Building and Planning Principles (London: Kegan Paul International, 1986). For criticism of Hakim's book, see Nezar Alsayyad, Cities and Caliphs: On the Genesis of Arab Muslim Urbanism (New York: Greenwood Press, 1991), 38.

12 Jean-Pierre Van Staëvel, 'Les usages de la ville: Discours normatif, habitat et construction urbaine dans l'Occident musulman médiéval (Xe-XIVe siècles)', 3 vols. (Ph.D. dissertation, University of Lyon II 'Lumière', 2000). An extract of this dissertation has since been published as idem, 'Savoir faire et le faire savoir: L'expertise judiciaire en matière de construction, d'après un auteur tunisois du 8e/14e siècle', Annales Islamologiques 35 (2001): 627-62. The other publications on the subject comprise Hisham Mortada, Traditional Islamic Principles of Built Environment (London: RoutledgeCurzon, 2003); Hentati Nejmeddine, 'La rue dans la ville de l'Occident musulman médiéval d'après les sources juridiques malikites', Arabica 50/3 (2003): 273-305; L'urbanisme dans l'Occident musulman au Moyen Âge: Aspects juridiques, ed. Patrice Cressier, Maribel Fierro, and Jean-Pierre Van Staëvel (Madrid: Casa de Velázquez/ Consejo Superior de Investigaciones Científicas, 2000); Mustapha Ben Hamouche, Fiqh al- ${ }^{c}$ umrān al-islāmī: Min khilāl al-arshīf al- ${ }^{c} u t h m a \bar{n} \bar{\imath}$ al-jazāa irī (956/1549-1246/1830) (Dubai: Dār al-Buhūth li-1-Dirāsāt al-Islāmiyya waIhyyā' al-Turāth, 2000); idem, 'Sight Restrictions in Maghrib Muslim Architecture', Intellectual Discourse (Malaysia) 7/2 (1999): 133-54; Moncef M'halla, 'La médina: Un art de bâtir', Africa: Fouilles, monuments et collections archéologiques en Tunisie 12, Special issue: Arts et traditions populaires (1998): 33-98; Akel I. Kahera and Omar Benmira, 'Damages in Islamic Law: Maghribi Muftis and the Built Environment (9th-15th Centuries CE)', Islamic Law and Society 5/2 (1998): 131-64; Akel Ismail Kahera, 'Building, Dwelling and Reasoning: A Discourse on Maliki Legal Practice and the "Ordering" of Habitat in the Medieval Maghrib' (Ph.D. dissertation, Princeton University, 1997); Khālid Muhammad Muștạā 'Azab, 'Takhṭịt wa-'imārat al-mudun alislāmiyya', Kitāb al-umma (Qatar) 58 (1997): 9-141; Jean-Pierre Van Staëvel, 'Casa, calle y vecindad en la documentación jurídica', in Casas y palacios de al-Andalus, 53-61; Farid Ben Slimane, 'Ibn al-Rāmī et l'art de bâtir', in Itinéraire du Savoir en Tunisie: Les temps forts de l'histoire tunisienne, ed. Hassen Annabi, Mounira Chapoutot-Remadi, and Samia Kamarti (Paris: CNRS Editions, 1995), 78-83; Farid Ben Slimane, 'Entre Ibn Al Imām le Tudèlien (mort en 996) et Ibn Al Rāmī le Tunisois (mort après 1333)', Sharq Al-Andalus 8 (1991): 109-12; Leonor Fernandes, 'Habitat et prescriptions légales', in L'habitat traditionnel dans les pays musulmans autour de la Méditerranée, 
The merit of these publications notwithstanding, none satisfactorily researches the origins and, more importantly, the extent of this legal engagement with medina architectural space. When such research is done, it becomes clear that this engagement is not restricted to the handful of well-known, discrete works, such as those by the aforementioned Ibn alImām and Ibn al-Rāmī. Rather, it becomes possible to talk of an entire corpus of Sunni Islamic law pertaining to the Arab-Muslim medina's architectural environment, composed essentially of legal opinions (aqwāl) and court records (nawāzil). This corpus dates from approximately the tenth to the nineteenth centuries and constitutes the main body of fiqh albunyān (building law), within which the special importance of (primarily domestic) "walls" is reflected in two of the titles it comprises: al-Marjī al-Thaqafi's (d. c. 1200) Kitāb al-hìțān (The book of walls) and "İsā b. Dīnār's (d. 827) Kitāb al-jidār (The book of the wall). ${ }^{13}$ The purpose of the current article is to present this research and to propose considering the corpus a discourse that established a legal aesthetic of urban architectural space. ${ }^{14}$

The History and Genealogy of fiqh al-bunyān

As with much of Islamic law, the origins of fiqh al-bunyān can be traced to the Qur ${ }^{\circ} \bar{n}$ and Sunna, but little more than perfunctorily, especially with regard to the Qur ${ }^{\curvearrowright} \bar{a}$. The Qur ān contains no verses from which rulings (ahkām) are derived for fiqh al-bunyān, only two or three verses

Rencontre d'Aix-en-Provence (6-8 juin 1984), Vol. 2, L'histoire et le milieu (Cairo: L'Institut Français d'Archéologie Orientale, 1990), 419-26; Jamel Akbar, Crisis in the Built Environment: The Case of the Muslim City (Singapore: Concept Media Pte. Ltd., 1988); and André Raymond, 'Espaces publics et espaces privés dans les villes arabes traditionnelles', MaghrebMachrek 123 (1989): 194-201.

13 Regarding publication details for these titles, the latter (K. al-jidār $)$ is not extant, known only through citation in other works; and because the former $(K$. al-hịtāan) is something of a palimpsest, with four different authors/contributors, two versions of it exist in print, each attributed differently. The one used in this article is al-Shaykh al-Marjī al-Thaqafī, Kitāb al-ḥ̂țān: Ahkām al-țuruq wa-lsuṭūh wa-l-abwāb wa-masīl al-miyāh wa-l-hịṭān fì l-fiqh al-islāmī, ed. Muhammad Khayr Ramaḍān Yūsuf (Beirut: Dār al-Fikr al-Mucāạir, 1994), hereafter cited as 'Kitāb al-ḥịtān' only. The second is ' Umar b. 'Abd al- ${ }^{c}$ Azīz Ṣadr alShahīd (d. 1141), Kitāb al-hịṭ̂̄n: Dirāsa fiqhiyya li-aḥkām al-binā ${ }^{\supset}$ wa-l-irtifāq, ed. ${ }^{\mathrm{c}}$ Abd Allāh Nadhīr Aḥmad (Jeddah: Markaz al-Nashr al- ${ }^{\mathrm{C}}$ Ilmī, Jāmi ${ }^{\mathrm{c}}$ at alMālik ${ }^{\mathrm{c}}$ Abd al- ${ }^{\mathrm{c}}$ Azīz, 1996).

14 That a primary theme of the corpus is domestic walls will be seen below. 
that refer obliquely to urban architectural matters and which are occasionally cited in the corpus in the context of rulings derived from elsewhere. For example, regarding the harm (darar) caused by smoke from public ovens and baths, Ibn al-Rāmī cites the verse: 'Then watch for the day when the sky will bring forth a kind of smoke plainly visible. ${ }^{15}$ The actual ruling forbidding such smoke is, however, based on opinions established by the eponymous leader (imām) of the Maliki law school, Mālik b. Anas (d. 796), and his disciples. ${ }^{16}$

If the Qur'an occupies only an auxiliary position in fiqh al-bunyān, the corpus's substantive material from Islamic law's two primary sources comprises but hadìths. In the hadìth, the Prophet is reported engaging with the urban environment in more than an extralegal capacity. For example, 'Do you know the rights of the neighbour? . . . You must not build to exclude the breeze from him, unless you have his permission'; ${ }^{17}$ and 'A neighbour has pre-emption rights over his neighbour's property. If they share common access and the neighbour is absent, then the other should wait for his return [before selling, etc.]. ${ }^{18}$ Some of these hadiths find their way into the corpus. Common ones include: 'A neighbour should not forbid his neighbour from inserting wooden beams in his

\footnotetext{
15 Qur`ān 44:10. Ibn al-Rāmī, 300.

16 Ibid., 300-301. In Ibn al-Rāmī’s text, eleven Qurª̄nic verses are cited, only three of which have some, if any, urban architectural relevance; the other eight being of even broader import, for example the influential but general 'Hold to forgiveness, and command what is right' (7:199). Ibn al-Rāmī, 276. The other verses cited by Ibn al-Rāmī are 50:9, 43:33, 23:18, 21:32, 9:107, 7:85, 7:58, 3:9, and 3:7. Ibn al-Rāmī (2), 253. In Ibn al-Imām's text, two Qur'ānic verses are cited: 9:107, and 21:78. Ibn al-Imām, 2: 207. In Ibn Sahl's (d. 1094) text, 7:85 is cited. Abū l-Aṣbagh ' ${ }^{\mathrm{I}} \overline{\mathrm{s}} \mathrm{a}$ b. Sahl al-Andalusī, Wathă $\bar{a}^{\supset} q$ fi shu'ūn al- 'umrān fì l-Andalus 'al-Masājid wa-l-dūr' mustakhraja min makhtūt ț

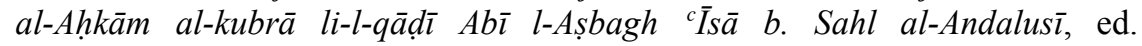
Muhammad ${ }^{\mathrm{c}}$ Abd al-Wahhāb Khallāf (Cairo: al-Mațba ${ }^{\mathrm{c} a}$ al- ${ }^{\mathrm{c}}$ Arabiyya alHadītha, 1983), 99, 101, hereafter cited as 'Ibn Sahl' only. I have found no Qur ${ }^{\circ} \bar{a}$ nic verses cited in Kitāb al-hịt ân.

${ }^{17}$ Abū Bakr Muhammad b. Ja ${ }^{c}$ far b. Muhammad b. Sahl al-Sāmarrī al-

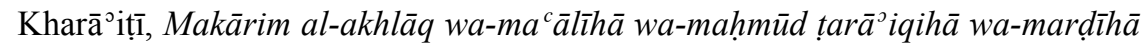
(Beirut: Dār al-Fikr, n.d.), 59.

18 Majd al-Dīn al-Mubārak b. Muḥammad b. al-Athīr al-Jazarī, Jāmic al-uṣūl fì ahādìth al-Rasūl, ed. ' Abd al-Qādir al-Arnā̄ōțt, 5 vols. (Beirut: Dār al-Fikr, 1995), 1: 582. See also the appendix 'Selected Sayings of the Prophet' in Hakim, Arabic-Islamic Cities, 146-56.
} 
wall', ${ }^{19}$ 'If you disagree about the width of a street, it is made seven cubits'; ${ }^{20}$ and, 'Whoever wrongfully appropriates a foot of land will [on the Day of Resurrection] be enclosed in the Seven Earths'. ${ }^{21}$ As with the Qur ${ }^{\bar{a}} \mathrm{a}$, however, these and other hadiths ultimately serve little more than a supplementary role. The width of medina thoroughfares, for example, is frequently either more or less than the seven cubits recommended by the hadith. Furthermore, many are the occasions in fiqh albunyān where no hadith is cited in relation to rulings. ${ }^{22}$ The one that does get frequent mention is of general import, without specific bearing upon urban architectural matters, namely, 'In Islam there is no harm or return of harm'. ${ }^{23}$

In the near-absence of programmatic material from the Qur ${ }^{\circ} \bar{n}$ and hadith, one must look to the eponymous leaders of the law schools, most especially the Maliki and Hanafi, to find the practical origins of the corpus. ${ }^{24}$ In these leaders' teachings, related and compiled by disciples, lies the first properly substantive architecture-related Islamic law. ${ }^{25}$ For the

19 Abū al-Husayn Muslim b. al-Hajjāj al-Qushayrī, Șaḥịh Muslim bi-sharḥ al-Nawāwī, ed. 'Ișām al-Șabābițī et al., 11 vols. (Cairo: Dār al-Hadīth, 1994), k. al-musāqāt, bāb 29, raqm 136. Cited in Ibn al-Rāmī, 294; and Ibn al-Imām, 2: 1, 8 .

${ }^{20}$ Muslim, Șahīh Muslim, k. al-musāqāt, bāb 31, raqm 143. Cited in Ibn alRāmī, 430, and Ibn al-Imām, 2: 145.

${ }^{21}$ Muslim, Șaḥịh Muslim, k. al-musāqāt, bāb 30, raqm 142. Cited (with minor variations) in Ibn al-Rāmī, 398-99; and Ibn al-Imām, 2: 125.

${ }^{22}$ In all of Kitāb al-hịtân, for example, I have found cited just one hadīth: an account of the Prophet's companion Hudhayfa b. al-Yamān (d. 656) judging a quarrel concerning a hut (khuṣs). Kitāb al-hịțān, 44; also cited in Ibn al-Rāmī, 276-77. The hadīth is collected in Abū ${ }^{c}$ Abd Allāh Muhammad b. Yazīd alQazwīnī b. Mājah, Sunan al-hājiz Abī ${ }^{c}$ Abd Allāh Muḥammad b. Yazīd alQazwīn̄ b. Mājah, ed. Muhammad Fūād ${ }^{\mathrm{c}} \mathrm{Abd}$ al-Bāqī, 2 vols. ([Cairo]: Dār Iḥyā' al-Kutub al- ' Arabiyya, 1952), k. al-aḥkām, bāb 18, raqm 2365.

23 'Lā ḍarar wa-lā ḍirār [fī l-Islām].' Mālik b. Anas, al-Muwațta li-imām al$a^{\circ}$ imma ${ }^{c}$ ālim al-Madīna Mālik b. Anas, ed. Muhammad Fuād ${ }^{\mathrm{c}} \mathrm{Abd}$ al-Bāqī, 2 vols. ([Cairo?]: Dār Ihyā̄o al-Turāth al- ${ }^{\mathrm{c}} A$ arabī, n.d.), k. al-aqḍiya, bāb 26, raqm 31 [vol. 2, p. 745], and k. al-mukātab, bāb 11, raqm 13 [vol. 2, p. 805].

24 For the Shafici school's engagement with walls, see Otto Spies, 'Islamisches Nachbarrecht nach schafäitischer Lehre', Zeitschrift für vergleichende Rechtswissenschaft 42 (1927): 393-421.

25 These orally transmitted teachings came to exert as decisive an effect on the development of law school identity and doctrine as the works traditionally attributed to the leaders themselves. See, inter alia, Schacht, An Introduction to 
Hanafi school, to which belongs, for example, Kitâb al-hịt ân, the principal compilations are by the two disciples considered by some to be the true founders of the Hanafi law school: $Y^{c}{ }^{c} q u \bar{b}$ Abū Yūsuf (d. 798) and Muhammad al-Shaybānī (d. 804). For the Maliki school, to which belong, for example, the texts of Ibn al-Rāmī and Ibn al-Imām, the principal compilation is the multi-volume al-Mudawwana al-kubrā. Compiled by the celebrated qā $\bar{d} \bar{l}$ of Qayrawān, Sahnūn (d. 855), the contents are a narration from Mālik's most prominent disciple, Ibn alQāsim (d. 806).

Taking the Mudawwana as an example, although its engagements with the urban architectural environment are rarely architecture-specific and include additional issues such as property bequests (wașaya $\bar{a}$ ), they establish the pattern and many of the precedents for figh al-bunyān. For instance, in the chapter pertaining to property division and allotment (qisma), Saḥnūn asks Ibn al-Qāsim a hypothetical question about someone prevented by neighbours from building an oven, hammam or mill on his empty lot ( ${ }^{c}$ arșa). Ibn al-Qāsim responds: 'If what is built will harm the neighbours because of smoke or other comparable nuisances, then they can prevent the project, because Mālik taught ( $q \bar{a} l a)$ that one is prevented from harming neighbours. ${ }^{26}$ Some pages earlier in the same chapter, Ibn al-Qāsim is asked about the division of streets and walls (qismat al-tarīq wa-l-jidār). For a wall that is to be divided between two co-proprietors, he responds: 'I did not hear anything from Mālik on this matter, but my opinion (ara $\bar{a}$ ) is that so long as no harm comes from it when it is divided, then it may be divided. ${ }^{27}$ These and similar generic teachings find their way into fiqh al-bunyān.

Roughly contemporary with Saḥnūn and Ibn al-Qāsim, other disciples and associates of Mālik were also giving opinions and judgements concerning the urban architectural environment. Such figures include ${ }^{\mathrm{c}} \mathrm{Abd}$ Allāh b. Wahb (d. 813); Ashhab (d. 819); ${ }^{28}$ Ibn al-Mājishūn (d. 827);

Islamic Law (Oxford: Oxford University Press, 1964), 57-68; N. J. Coulson, A History of Islamic Law (Edinburgh: Edinburgh University Press, 1964), 51-52; and Christopher Melchert, The Formation of the Sunni Schools of Law, 9th-10th Centuries C.E. (Leiden: Brill, 1997), 23, 60.

${ }^{26}$ Mālik b. Anas, al-Mudawwana al-kubrā li-l-imām Mālik b. Anas al-

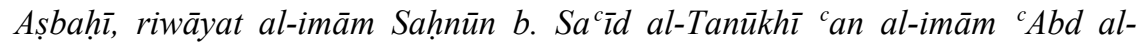
Raḥmān b. Qāsim, 6 vols. (Beirut: Dār al-Fikr, 1998), k. al-qisma, vol. 5, p. 2569.

27 Ibid., k. al-qisma, vol. 5, p. 2560.

28 Ashhab b. ${ }^{\mathrm{c}}$ Abd al- ${ }^{\mathrm{c}}$ Azīz al-Qaysī. 


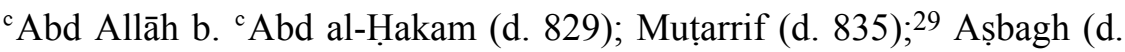
840); ${ }^{30}$ and Muhammad b. Sahnūn (d. 870). Included, too, are ${ }^{\mathrm{c}} \mathrm{Abd}$ alMālik b. Habīb (d. 853), author of an influential imitation of the Mudawwana, the Wādiha; ${ }^{31}$ and Abū ${ }^{\mathrm{c}}$ Abd Allāh Muhammad b. Ahmad al- ${ }^{\mathrm{C}} \mathrm{Utb} \overline{1}$ (d. 869), author of the Mudawwana's alleged supplement, the Mustakhraja, or 'Utbiyya. From these scholars' teachings fiqh al-bunyān also takes its shape. Ibn al-Rāmī acknowledges as much in the introduction to his contribution to the corpus:

This is a book that compiles architecture-related questions concerning walls, the elimination of harm, and gardens and mills, from [the following sources]: government administration records, the books of our contemporaries, the court records of $q \bar{a} d \bar{l} \overline{\mathrm{s}}$, and the fatwas of muftis ${ }^{32}$ from the Mudawwana, the Wādiha, and the ${ }^{c}$ Utbiyya, the book of ${ }^{\mathrm{c}} \mathrm{Abd}$ Allāh b. ${ }^{\mathrm{c}} \mathrm{Abd}$ al-Hakam, the book of Ibn Sahnūn, the book of Ibn ${ }^{\mathrm{c}} \mathrm{Abdūs},{ }^{33}$ and the Nawādir, ${ }^{34}$ from what notaries follow in their legal formularies (watha $\left.\bar{a}^{3} i q\right),{ }^{35}$ such as the notaries Ibn alQāsim ${ }^{36}$ and Ibn Mughìth, ${ }^{37}$ and from [the formulary called] al-Mutititiyya ${ }^{38}$ and [lastly], from what $q \bar{a} d \bar{l} \overline{\mathrm{s}}$ follow of the judgements (ahkām) of Ibn Abi Zamanīn, ${ }^{39}$ the judgements of Ibn Hishām ${ }^{40}$ and the judgements of our master,

${ }^{29}$ Muțarrif b. ${ }^{\text {c} A b d ~ A l l a ̄ h ~ b . ~ M u t ̦ a r r i f ~ . ~}$

${ }^{30} \mathrm{Abū}{ }^{\mathrm{c}}$ Abd Allāh Așbagh b. al-Faraj.

31 Al-Wädiha fí l-sunna wa-l-fiqh.

32 'Hādhā kitāb jumi 'at fīhi masā̄a il al-abniya fỉ l-jidār wa-nafy al-ḍirār wa-lghurūs wa-l-arḥiya min ummahāt dawāwīn wa-kutub al-muta ${ }^{0}$ akhkhirīn wanawāzil al-qựāt wa-masā̄il al-muftīn.'

33 Muhammad b. Ibrāhīm b. 'Abdūs al-Qayrawānī (d. 874).

${ }^{34}$ Abū Muḥammad ${ }^{\mathrm{C}}$ Abd Allāh b. ${ }^{\mathrm{c}}$ Abd al-Raḥman b. Abī Zayd al-Qayrawān̄̄, al-Nawādir wa-l-ziyādāt ${ }^{c}$ alā mā fì l-Mudawwana min ghayrihā min alummahāt, ed. 'Abd al-Fattāh Muhammad al-Ḥulw et al., 15 vols. (Beirut: Dār al-Gharb al-Islāmī, c. 1999).

35 The formularies would likely have been similar to the architecture-related wath $\bar{a}^{\supset} i q$ documents presented in Ibn al- ${ }^{\mathrm{C}} \mathrm{Atțār}, K i t \bar{a} b$ al-wath ${ }^{\supset} i q$ wa-l-sijillāt li-l-faqīh al-muwaththiq Muhammad b. Ahmad al-Umawī al-macrūf bi-Ibn al${ }^{c}$ Atțār (330-399 AH) (Formulario notarial hispano-árabe), ed. Pedro Chalmeta and Federico Corriente (Madrid: Academia Matritense del Notariado, Instituto Hispano-Árabe de Cultura, 1983), 117-23.

36 c Alī b. Yahyā b. Qāsim al-Jazīīi (d. 1189).

${ }^{37}$ Yūnus b. Muhammad b. Mughīth (d. 1037).

${ }^{38}$ Composed by ${ }^{c}$ Alī b. ${ }^{c}$ Abd Allāh al-Anșārī al-Mutîțīi (d. 1174).

39 Ibn Abī Zamanīn of Andalusia (d. 1008), to whom the authorship of alMuntakhab fi l-ahkām is ascribed.

${ }^{40}$ Ibn Hishām of Cordoba (d. 1209), author of the extant Mufíd al-hukkām. 
the learned, the ascetic, the devout, and God-fearing Abū Ishāq b. ${ }^{\mathrm{c}}$ Abd alRafi $^{{ }^{c}},{ }^{41}$ may God grant him success and guide him. ${ }^{42}$

The years 950-1350 mark a particular period for fiqh al-bunyān that might with due levity be considered a golden age, for during this time at least five extant discrete texts on architecture-related law were written: the aforementioned Kitāb al-hịtān and books of Ibn al-Imām and Ibn alRāmī, as well as one by Muḥammad b. 'Abd Allāh al-Zubayrī (d. 989), Kitāb al-abniya (The book of buildings), ${ }^{43}$ and another by Ibn Rushd 'al-

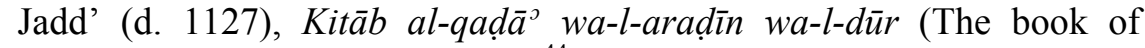
jurisdiction, terrains, and houses). ${ }^{44}$ It is these discrete works, as well as two or three others written, or reported written outside of this period, ${ }^{45}$ that has led at least one contemporary scholar to consider the corpus a genre of Islamic law. ${ }^{46}$ Their importance notwithstanding, these discrete works are, however, just one part of a much larger body of legal writings on the built environment, which has no common literary basis and is not, therefore, a genre, but a looser, uncontrived, and more pervasive formation, what the social sciences refer to as a discourse. ${ }^{47}$ For the available evidence suggests that the more regular form of fiqh al-bunyān comprises chapters (sg. kitāb or $b \bar{a} b$ ), sections (sg. faṣl), or sometimes just individual cases of longer legal works. In other words, indiscrete texts

${ }^{41} \mathrm{Ibn}{ }^{\mathrm{c}} \mathrm{Abd}$ al-Rafî̀ ${ }^{\mathrm{c}}$ (d. 1332), chief $q \bar{a} d \underline{\imath} \mathrm{l}$ of Tunis, Ibn al-Rāmī’s teacher in legal matters, and author of the extant $M u^{c} \bar{i} n$ al-quḍāt wa-l-hukkām.

42 Ibn al-Rāmī, 274-75.

43 As cited in Nejmeddine, 'La rue dans la ville de l'Occident musulman médiéval', 282. It is not extant.

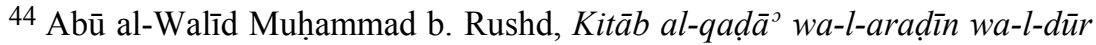
(Rabat: Bibliothèque Générale à Rabat, MS no. 424).

45 Muhammad b. Ibrāhīm b. ${ }^{\mathrm{c}}$ Abdūs b. Bashīr (d. 874), Kitāb al-dūr (The book of houses) (not extant), as cited in Qāḍ̄ '⿳亠口冋ạ, Tartīb al-madārik wataqrīb al-masālik li-macrifat a lām madhhab Mālik, ed. Muhammad Sālim Hāshim, 2 vols. (Beirut: Dār al-Kutub al-' Ilmiyya, 1998), 1: 434; Muḥammad al-Barūdī (d. 1831), Fatḥ al-Raḥmān fì mas alat al-tanāzu ${ }^{c}$ fi-l-bunyān (The victory of God in building disputes) (Tunis: Bibliothèque Nationale de Tunis, MS no. 3933), as cited in M'halla, 'La médina', 40, n. 16; and Abū ' Abd Allāh Muhammad b. Hasan Bayrām I (d. 1900), Risāla fì l-ḥa it al-munhadim (Treatise on the falling wall) (Tunis: Bibliothèque Nationale de Tunis, MS no. 187), also as cited in M'halla, 'La médina', 40, n. 16.

46 M'halla, 'La médina', 38.

47 See, for example, Michel Foucault, The Archaeology of Knowledge, trans. A. M. Sheridan Smith (New York: Pantheon Books, 1972), passim. 
forming but one element of Islamic law's exhaustive literature.

By and large, the legal works to which these chapters and sections belong are either compilations of judgements of the type mentioned by Ibn al-Rāmī or compilations of fatwas of the type implied by him. Of the two earliest, but non-extant, allegedly discrete texts of fiqh al-bunyān, namely, Ibn Dīnār's (d. 827) aforementioned Kitāb al-jidār and Ibn 'Abd al-Hakam's (d. 829) Kitāb al-qaḍa ${ }^{\supset}$ fì l-bunyān (The book of jurisdiction in building), the second is now thought not to have been a book (kitāb), but a chapter (also kitāb) of a legal compilation, alMukhtașar al-kabir fi l-fiqh. ${ }^{48}$ The first text was perhaps the same. ${ }^{49} \mathrm{Ibn}$ Sahl's (d. 1094) 'Mosques and houses' certainly belongs to a compilation of judgements, namely, his al-Ahkām al-kubrä $;^{50}$ as does Ibn Abī Zayd al-Qayrawān̄̄'s (d. 996) 'Jurisdiction in building', which belongs to his Nawādir. ${ }^{51}$ Similarly, Ibn Farhūn's (d. 1396) 'The leaning wall' belongs to his Tabșirat al-hukkām; ${ }^{52}$ Ibn Hishām's (d. 1209) 'The book [or chapter] of claims regarding the wall' belongs to his Mufid alhukkām; ${ }^{53}$ and al-Bājî̀s (d. 1081) 'The division of [goods and chattels] between partners, the hire of [those qualified to make and record divisions], and all claims regarding walls' and 'On the elucidation of judgements [regarding] harm, the inviolable perimeters of wells, gifts, acts of mortmain, and charitable donations' belong to his Fușül al-ahkām. ${ }^{54}$

\footnotetext{
48 Jonathan E. Brockopp, Early Maliki Law: Ibn ${ }^{c}$ Abd al-Hakam and his Major Compendium of Jurisprudence (Leiden: Brill, 2000), 62. Qāḍ̄ ' Iyāḍ (d. 1149) lists the title as one of Ibn 'Abd al-Hakam's works, never implying it might have been only a chapter of a longer work. Qāọ̄i 'Iyād, Tartīb almadārik, 1: 305.

49 This work is also cited by Qāḍī ' Iyāọ. Ibid., 1: 375.

50 To the best of my knowledge, the only edited version of al-Ahkām al$k u b r a \overline{~ w a s}$ originally presented as the editor's doctoral thesis at St. Andrew's University: Abū l-Așbagh 'Īsā b. Sahl b. ${ }^{c}$ Abd Allāh al-Asdī al-Jiyyān̄̄, Dīwān al-aḥkām al-kubrā: al-Nawāzil wa-l-aclām li-Ibn Sahl, ed. Rashīd al-Na ${ }^{c} \overline{1} m \overline{1}, 2$ vols. (Riyad: R. al-Nacīmī, 1997).

51 Ibn Ab̄̄ Zayd al-Qayrawānī, al-Nawādir wa-l-ziyādāt, 11: 93-112.

52 Burhān al-Dīn Ibrāhīm b. ${ }^{c}$ Alī b. Abī l-Qāsim b. Muhammad b. Farhūn, Tabșirat al-ḥukkām fì ușūl al-aqụiya wa-manāhij al-aḥkām, ed. Țāhā c Abd al$\mathrm{Ra}^{\circ} \overline{\mathrm{u} f ~} \mathrm{Sa}^{\mathrm{c}} \mathrm{d}, 2$ vols. in 1 binding (Cairo: Maktabat al-Kulliyyāt al-Azhariyya, 1986), 2: 339-40.

53 As cited by Ben Slimane in Ibn al-Rāmī (2), 20.

${ }^{54}$ Abū al-Walīd Sulaymān b. Khalaf al-Bājī, Fuṣūl al-aḥkām wa-bayān mā maḍa ${ }^{c}$ alayhi $l-{ }^{c}$ amal ${ }^{c}$ inda l-fuqaha ${ }^{\supset}$ wa-l-hukkām, ed. al-Bātūl b. ${ }^{c}$ Alī (Rabat: Wizārat al-Awqāf wa-l-Shuº̄n al-Islāmiyya li-l-Mamlaka al-Maghribiyya, 1990),
} 
Regarding the fatwa compilations, two categories exist: those limited to a single mufti, and those comprising fatwas from a number of muftis. To the first category belongs, for example, the compilation of Ibn Rushd 'al-Jadd' ${ }^{55}$ Scattered in it are fatwas such as 'A question concerning one who joins his wall to the wall of his neighbour'; '. 'On overlooking houses from [a] minaret'; ${ }^{57}$ and 'On one who installs a door or shop opposite the door of his neighbour's house on a through-passage (zuqāq $n \bar{a} f i d h),{ }^{58}$ To the second category of fatwa compilations belong, for example, al-Burzulî̀'s (d. 1438) Jāmic masa $\bar{a}^{\supset} i l$ al-ahkāmm; ${ }^{59}$ al-Wansharīsī's (d. 1509) al-Mi ${ }^{c} y \bar{a} r$ al-mu ${ }^{c} r i b ;{ }^{60}$ and al-Wazzānī's (d. 1924) al-Nawāzil al-jadīda al-kubrā and al-Nawāzil al-șugrā ${ }^{61}$ In these works are found numerous architecture-related fatwas, mostly in the chapters pertaining to property division and allotment, partnership (sharika), and, especially, harm. ${ }^{62}$

$315-48$.

55 Abū al-Walīd Muhammad b. Aḥmad b. Aḥmad b. Rushd, Fatāwā Ibn Rushd, ed. al-Mukhtār b. Țāhir al-Talīlì, 3 vols. (Beirut: Dār al-Gharb al-Islāmī, 1987).

56 Ibid., 3: 1578.

57 Ibid., 2: 1246.

58 Ibid., 1: 169.

59 Al-Burzulī, Jāmic masāàil al-ahkām bi-mā nazala min al-qaḍāyā bi-lmuftīn wa-l-hukkām (Tunis: Bibliothèque Nationale de Tunis, MS no. 4851), as cited in Nejmeddine, 'La rue dans la ville', 274, n. 2.

${ }^{60}$ Ahmad b. Yahyā al-Wansharīis̄i, al-Mi ${ }^{c} y \bar{a} r$ al-mu ${ }^{c} r i b$ wa-l-jāmi ${ }^{c}$ almughrib ${ }^{c}$ an fatāwā ahl Ifrìqiya wa-l-Andalus wa-l-Maghrib, ed. Muḥammad Hajjīi, 13 vols. (Rabat: Wizārat al-Awqāf wa-l-Shu ūn al-Islāmiyya li-lMamlaka al-Maghribiyya, 1981-83).

${ }^{61}$ Abū ${ }^{c} \bar{I} s a ̄$ Sīdī Muḥammad al-Mahdī b. Muḥammad b. Muhammad b. alKhaḍir al-Wazzānī, al-Nawāzil al-șughrā al-musammā bi-l-Minah al-sāmiya fíl-nawāzil al-fiqhiyya, 4 vols. (Rabat: Wizārat al-Awqāf wa-l-Shu'ūn alIslāmiyya li-l-Mamlaka al-Maghribiyya, c. 1993); idem, al-Nawāzil al-jadīda al-kubrā fì-mā li-ahl Fās wa-ghayrihim min al-badw wa-l-qurā al-musammā bial-Mi ${ }^{c} y \bar{a} r$ al-jadīd al-jāmic al-mughrib ${ }^{c}$ an fatāwa a al-muta akhkhirīn min ${ }^{c}$ ulama ${ }^{\supset}$ al-Maghrib, ed. ${ }^{\mathrm{c}}$ Umar b. ${ }^{\mathrm{c}} \mathrm{Abb} a \bar{d}, 16$ vols. (Rabat: Wizārat al-Awqāf wa-l-Shu ${ }^{\circ} \bar{u}$ al-Islāmiyya li-l-Mamlaka al-Maghribiyya, c. 1998).

${ }^{62} \mathrm{See}$, for example, the chapter 'Cases of Harm, Flowing Water, and Building' of al-Burzulī's compilation ( $\mathrm{f}^{\mathrm{0}}$ 281-313, cited in Nejmeddine, 'La rue dans la ville', 283); the chapter 'Cases of Harm and Building [Matters]' of al-Wansharīis's collection (8: 435-87, and 9: 5-73); and the chapter 'Cases of Harm and Vindication' of al-Wazzānī’s Nawāzil al-jadīda (3: 459-520). 
If the more usual form of the corpus is chapters or sections of longer texts, history offers some reasons for the efflorescence of discrete works between 950-1350. In the introduction to his edition of Ibn al-Imām's text, Muhammad al-Naminnaj argues that the population increase in tenthcentury al-Andalus was the underlying cause of this work, for it resulted in a sudden, unlegislated strain being placed on the urban architectural fabric. ${ }^{63}$ A similar argument most probably applies to the other works, too. This is an acceptable proposition when one considers the uneven urban growth experienced throughout the Arab-Muslim world during the first seven centuries of Islam. The greatest growth occurred between the tenth to fourteenth centuries, ending with the Black Death from the mid1300s; exactly the time-frame of the corpus's 'golden age'. ${ }^{64}$ The proposition is also acceptable when one considers the extent to which solutions to new problems, arrived at in one locale, but not contained or known in the source books (ummahät) of the law schools, might have been found helpful for solving similar problems elsewhere. There are, for example, some twenty extant manuscripts of Ibn al-Rāmī's work in the contemporary Arab-Muslim world, a clear indication of its historical utility. ${ }^{65}$ Compiled in the form of generalized, viz., non-place specific legal cases plus their assessments (ahkām) ${ }^{66}$ these discrete works would have represented concise summaries of the principal teachings of a law school with regard to the architectural environment, as well as manuals of potential solutions. ${ }^{67}$

${ }^{63}$ Al-Namīnaj in Ibn al-Imām, 1: 53. Cf. a related argument in al-Hathloul, Tradition, Continuity and Change, 16, 138.

${ }^{64}$ Garcin, 'Le Caire et l'évolution urbaine des pays musulmans', 289-304. See also, idem, 'Le moment islamique (VIIe-XVIIIe siècles)', in Mégapoles méditerranéennes, 91-103.

${ }^{65} \mathrm{Ibn}$ al-Rāmī (2), 28-29. There are at least four extant copies of Ibn alImām's work, and a similar number of Kitāb al-hịțān. Ibn al-Imām, 1: 62-65; Ben Slimane, 'Entre Ibn al-Imām', 110, n. 6; Kitāa al-hịt țān, 10-12.

${ }^{66}$ Where a place is mentioned, it is either incidental or in relation to the discourse's application mechanism. The translation of ahkām as 'assessments' follows A. Kevin Reinhart, 'Transcendence and Social Practice: Muftis and Qādīs as Religious Interpreters', Annales Islamologiques 27 (1993): 14.

${ }^{67}$ For a later period of the discourse (from the end of the fifteenth century), Fernandes suggests as a cause of additional discrete works the desire of rulers to reform the often disorderly urban sites under their command. Idem, 'Habitat et prescriptions légales', 426. 
An Aesthetic of Space

It would be wrong to consider fiqh al-bunyān a prescriptive code for the upkeep and replication of the Arab-Muslim medina's architectural environment. Rather, the corpus represents a proscriptive legal aesthetic for helping achieve the same results; an aesthetic that came into force only when contested and/or transgressed. That is to say, fiqh al-bunyān records from a legal perspective building-related conflicts - contestations and/or transgressions - plus their solutions that occurred in, and referred to, the medina environment's semi-private and public spaces. It collapses these spaces to their generic architectural elements, commonly walls, effectively encoding the spaces for articulation in later texts of the corpus as well as in related discourses, for example the hisba discourse regarding the policing of markets and their environs. ${ }^{68}$ In this process, fiqh al-bunyān established and embodied a legal aesthetic of urban architectural space: a way of talking and thinking about, or judging this space, and hence, organizing it. ${ }^{69}$ This aesthetic was flexible, as it was informed by local custom ( ${ }^{c} u r f$ ) and commonly negotiated via an application mechanism responsive to local conditions: ${ }^{c}$ amal or its non-Maliki equivalent. ${ }^{70}$ By way of example of this process, listed below is a selection of case titles from the twelfth-century Kitāb al-hịtān. In the examples the conflicts have occurred long ago and been resolved, and the action of collapsing and encoding the architectural spaces to which they refer is complete:

If two men contest a party wall. On a wall between two neighbours and neither one has roofing [over it], and one of them permits the other to place a roof over the wall. Then he appears to him and says: 'Remove your roof!'

On a wall between the two houses of two men, neither man having used it for load-bearing purposes, and one of them wants to bear upon it one or two wooden beams.

If a man buys a wall and no mention is made of its land, the sale occurs on

${ }^{68} \mathrm{See}$, for instance, the neighbourhood dispute section of Kitāb Nișāb alihtisāb, as reproduced in Mawil Izzi Dien, The Theory and Practice of Market Law in Medieval Islam: A Study of Kitāb Nișāb al-Iḥtisāb of ' ${ }^{2}$ Umar $b$. Muhammad al-Sunāmī (fl. 7th-8th/13th-14th Century) (Warminster: E. J. W. Gibb Memorial Trust, 1997), 82-85.

${ }^{69} \mathrm{Cf}$. Abu-Lughod's comments on the 'system of property laws ... whereby a pattern of space was continually reproduced'. Idem, 'The Islamic City', 163.

${ }^{70}$ For a detailed treatment of this application mechanism, see Simon O'Meara, Space and Muslim Urban Life: At the Limits of the Labyrinth of Fez (Abingdon: Routledge, 2007), 39-48. 
the wall without the land. Then it is said to the purchaser: 'Remove your wall!';

If a man buys half a wall. On a collapsed wall: if one of two owners wants to rebuild it but the other refuses, can the latter be forced to rebuild it? ${ }^{71}$

For comparative purposes, whilst a similar engagement with the architectural space of medieval London is found in the Assisa de Edificiis, the origins of which probably date to the late-twelfth century, what appears unique to fiqh al-bunyān is its longevity and geographical reach. ${ }^{72}$ For the corpus is not an isolated text or two, but as proposed earlier, an institutionalized discourse. Precisely when it came to constitute such a discourse is difficult to say with certainty, but no later than the mid-tenth century, the starting point of what this article has called the discourse's 'golden age'.

Concerning the aesthetic established by this discourse, crucially it derives in part from an undatable type of architectural space that precedes the discourse, is collapsed and recorded in the discourse, and then maintained and perpetuated by it. The aesthetic cannot, therefore, be considered fully original to Islam, for there is no compelling reason to suppose that the type of space from which it first derives reflects more than a type of architecture in existence before the Prophet, his companions and successors, and inherited by them. Certainly, this space was later modified by Islam: the discourse's interventions regarding the placement of external doors and windows to ensure visual privacy are a good example, an architectural equivalent of the Qur ānic requirement for the covering of nakedness and vulnerability $\left({ }^{c} a w r a\right) .{ }^{73}$ But modification by Islam is not the same as origination by Islam, and hence the discourse cannot be used to prove the validity of the ahistorical concept

${ }^{71}$ Kitāb al-hịt ān, case titles cited in order of appearance.

72 Helena M. Chew and William Kellaway (eds.), London Assize of Nuisance 1301-1431: A Calendar (London: London Record Society, 1973), ix-xi, passim. My thanks to Dr. Catherine Batt for alerting me to this parallel. On the Islamic discourse's differences from Roman law and the Coutume de Paris, see Brunschvig, 'Urbanisme médiéval', 130, 140, 153, n. 1.

${ }^{73}$ Cf. Eli Alshech, "'Do Not Enter Houses Other Than Your Own": The Evolution of the Notion of a Private Domestic Sphere in Early Sunni Islamic Thought', Islamic Law and Society 11/3 (2004): 309-12. These interventions form an important part of the genre and have been the subject of extensive commentary by contemporary scholars. See, in particular, Hakim, ArabicIslamic Cities, 33-39; M'halla, 'La médina', 59-66; and Ben Hamouche, 'Sight Restrictions', passim. On the Qur ānic requirement for the covering of nakedness and vulnerability, see, for example, 24:58 and 33:13. 
of 'the Islamic city' mentioned at the start of this paper.

Of importance, too, for understanding the discourse is the fact that fiqh al-bunyān concerns the medina's semi-private and public space only; not the private, interior space of domestic houses. With reference to Henri Lefebvre's critical terminology of space, this is to say the discourse belongs to a society's representations of space, not its representational spaces. The former are the conceptualized spaces of professionals (scientists, planners, and so forth) that are 'tied to the relations of production and to the "order" which those relations impose, and hence to knowledge, to signs, to codes. ${ }^{, 74}$ The latter are the largely non-verbal, symbolic spaces that afford a shelter for the imagination and which are commonly found, for example, in the domestic house - 'one of the greatest powers of integration for the thoughts, memories, and dreams of mankind. ${ }^{75}$ Except as absences, lacunae of privacy $\left({ }^{c} a w r a\right)^{76}$ demarcated by the interventions preventing the overlooking $\left(i t t i i \bar{a}^{c}\right)$ of courtyard houses by muezzins atop their minarets, for instance, these representational spaces form no part of fiqh al-bunyān and await research. ${ }^{7}$

In the academic study of Islamic architecture and urbanism, it is usual to find the spaces of a city or building discussed in terms of the structures that define them. In that regard, such study operates similarly to fiqh al-bunyann: collapsing space according to the modalities of a discourse, that of Islamic art and architecture. Notwithstanding the obvious merits of this academic discourse, a question yet remains as to the nature of the knowledge it represents; for in collapsing and hence excluding

${ }^{74}$ Lefebvre, The Production of Space, 33.

${ }^{75}$ Gaston Bachelard, The Poetics of Space, trans. Maria Jolas (New York: The Orion Press, Inc., 1964; reprint, Boston: Beacon Press, 1994), 6. Cf. Lefebvre, The Production of Space, 147, 166.

${ }^{76}$ On this legal usage of ${ }^{c}$ awra, see Alshech, “"Do Not Enter Houses Other Than Your Own"', 309-12.

77 With reference to the representational space of houses only, although there exists no equivalent to Bachelard's celebrated Poetics of Space for the psychic dimensions of Muslim houses, Paul Wheatley has hinted at their significance. Paul Wheatley, 'Levels of Space Awareness in the Traditional Islamic City', Ekistics 42, no. 253 (Dec. 1976): 354. Perhaps the closest that has come to Bachelard's book is Joëlle Bahloul, The Architecture of Memory: A JewishMuslim Household in Colonial Algeria, 1937-1962, trans. Catherine du Peloux Ménagé (Cambridge: Cambridge University Press, 1996). See also, Carel Bertram, 'The Turkish House: An Effort of Memory' (Ph.D. dissertation, University of California, Los Angeles, 1998), esp. 1-30. 
space from the investigative framework, the discourse risks, on the one hand, being content with a reduced view of the world that each society creates, inhabits, and competes to reproduce. This is problematic, because a world collapsed of its space offers to knowledge a flattened picture, revealing little of the interactions and interrelations between things, and between things and people. Rarely, for example, is it satisfying to know only the outward, formal aspects of an architectural space - the history, appearance, and intended meaning of the madrasas, mosques, and mausoleums comprising a medina, say. One would also like to know the inner workings of this space; for in this space commingle what these monuments are in historical time and selectively frame out of time ${ }^{78}$ with the lives and beliefs of those subject to them. And from this space arise a society's representations of the world and the inhabitants' place in it, which in turn re-inform the space. ${ }^{79}$ On the other hand, in collapsing and excluding space from the investigative framework, the academic discourse also risks rejecting space as a nonideological phenomenon, when the struggles involved in instigating, maintaining, and replicating environments and their spaces suggest a different reality, as the involvement of ${ }^{c} u l a m \bar{a}^{\nu}$ in the neighbourhood disputes shows.

In the foregoing analysis of fiqh al-bunyān, I have attempted to provide a correction to these two risks. In presenting a clear statement regarding the reach and nature of the Arab-Muslim legal discourse, I hope to have contributed to the process of making historical ArabMuslim urban space increasingly accountable to academic thought.

78 'The time of architecture is a detained time; in the greatest of buildings time stands firmly still.' Juhani Pallasmaa, The Eyes of the Skin: Architecture and the Senses (Chichester: John Wiley \& Sons Ltd., 2005), 52.

${ }^{79} \mathrm{Cf}$. Richard van Leeuwen, 'Space as a Metaphor in Alf laylah wa-laylah: The Archetypal City', in Myths, Historical Archetypes and Symbolic Figures in Arabic Literature: Towards a New Hermeneutic Approach; Proceedings of the International Symposium in Beirut, June 25th-June 30th, 1996, ed. Angelika Neuwirth et al. (Beirut/Stuttgart: Franz Steiner Verlag, 1999), 493. 